\title{
Research in the Classroom: The Teaching of Economics and Gamification
}

\author{
https://doi.org/10.3991/ijet.v16i16.23479 \\ Jhonatan Alexander Moreno-Delacruz ${ }^{1}$, Isabel Cristina Rivera-Lozada $\left.{ }^{1}{ }^{\bowtie}\right)$, \\ Oriana Rivera-Lozada ${ }^{2}$ \\ ${ }^{1}$ Universidad del Cauca \\ ${ }^{2}$ South American Center for Education and Research in Public Health, Universidad Norbert \\ Wiener-Lima, Peru \\ irivera@unicauca.edu.co
}

\begin{abstract}
This paper presents the preliminary results of a proposal to facilitate the understanding of concepts and the logic of economy in university students who are not enrolled in the academic program of economics. This proposal is based on the simulation game called Strategies and Markets in Economics (Estrategias y Mercados en Economía - EMERCO), which resulted from a research process in the classroom. The methodology has a qualitative approach and a descriptive type, with an exploratory scope. This study shows the functioning of the game, the selection of the team according to mentality type and brain dominance, in accordance with the Herrmann Brain Dominance Instrument. The game has novel elements in its structure by bringing the real functioning of a market to the classroom, achieving better results in regard to grades and in the assimilation of the contents in introductory classes and fundamentals of economics in higher education.
\end{abstract}

Keywords-Education; gamification; educational innovation.

\section{Introduction}

The teaching of economics has evident challenges nowadays. The economic crisis in several countries leads us to rethink the possibilities of offering answers to the multiple economic challenges and the big social gaps, since the world's wealth increases, but most of the population suffer serious deprivation, which makes survival more difficult.

As a result, various demonstrations led by student movements have emerged in France, Greece, Spain and the United States. The groups of the outraged students make strong complains to the economic model, particularly, to the Schools and Faculties of Economics for the hegemonic and universalizing training, holding them responsible for the crisis that still exists in the world economy [1-3].

In addition to a clear ideological bias, the contents tend to be abstract and instrumentalized, which hinders their understanding and their association with reality. These restrictions are present both in students with specific economic training, as well 
as in students of other disciplines that include basic courses of economics. The latter have greater difficulty understanding, since the conceptual relationship with other disciplines is insufficient and demotivating, as it focuses on training for competitiveness and not for coexistence [4].

Since the 1960s, games and simulations have been designed and developed for learning in the classroom as a playful pedagogical strategy that offers interaction experiences in sensitive environments, whose potential was exploited two decades later with the introduction of video games that allow us to study the impact of games on the construction of critical thinking and problem solving $[5,6]$.

Our own university experience motivated us to do this research, to find initiatives that facilitate the learning process of the fundamentals of economics for noneconomists. Therefore, we sought to problematize the teaching of economics in scenarios where it has difficulties. It involves researching the classroom to learn extensively about how students learns and explore mechanisms that facilitate learning [7, 8], motivation for the design of the Emerco pedagogical strategy.

The literature on economic education shows traditional techniques strongly rooted in the classroom [9] that contrast with the research that indicates the use of gamification as a pedagogical strategy that incorporates game elements in non-game scenarios, helps to solve difficulties in the understanding of economic concepts, and promotes active learning, achieving greater student participation in their own learning process $[10,11]$. As a result, the literature shows research on simulation games with and without computers in competitive and cooperative tournaments that show improvements in students' academic performance [12].

In this sense, this research proposes a pedagogical strategy based on gamification for economic fundamentals classes, focused on the functioning of the market, one of the main categories in the study of economics, and an essential part of the basic economic models that a student needs to know to understand the dynamics of an economic system.

In addition, this study is relevant because it improves the quality of university education by promoting meaningful learning processes, explores pedagogical alternatives for cognitive areas with difficulties, represents an opportunity to incorporate educational innovations in the university classroom and promotes changes that involve fun learning experiences for students.

\section{Methodological elements}

The implemented methodology has a qualitative approach, with a descriptive scope of the main results of the implementation of the pedagogical strategy based on gamification elements. It is developed in three methodological moments: exploratory phase, regarding the relationship between the teaching of economics and gamification, introductory phase in regard to the game and its intentionality, and finally, preliminary results on the teaching-learning strategy. 


\subsection{Exploratory moment}

Training in economics is important for administration and social sciences professionals' decision making when facing increasingly complex situations that demand analysis and interpretation from different perspectives with a marked tendency to develop interdisciplinary processes.

Considering that the study of economics is accompanied by abstract theoretical concepts that complexify the explained realities [13]. Thus, pedagogical innovations are imperative to achieve learning objectives [14], particularly gamification, because it improves the teaching-learning process, achieving efficiency and appropriateness in learning $[15,16]$.

The approaches to the economics are generally through introductory and foundation courses that offer basic economic notions, without directly addressing the relationship with other disciplines, which leads students from other disciplines to think that learning about it is a difficult experience [17].

Specifically, some authors in the field of economic education state that classes with a combination of pedagogical strategies enable greater appropriation of conceptual elements; thus, games in the classroom are a type of pedagogical mediation that helps to improve the learning process of economic topics $[18,19]$. Gamification includes particular elements of the introduction of games in the classroom, being a component that revitalizes teaching [20] that uses game elements in non-game scenarios to increase student participation but also involves determining the guidelines for its use $[21,22]$.

Gamification, as an innovative pedagogical strategy, has become especially important recently, considering the growing number of research studies on the subject, as well as their scientific quality [23]. In addition to having an impact on better understanding, it has the ability to lead students in a fast and fun way, through a series of predefined actions that encourage them to become actively involved in their own learning process and stimulates interest in the class [20, 24].

Moreover, it provides students with opportunities to develop skills in the assumption of commitments, motivating and generating interest in topics and self-learning [25] by framing access to knowledge in attractive experiences that propose the social appropriation of knowledge while developing soft skills of cooperation and social interaction [26].

Evidence indicates that the introduction of gamification elements tends to increase interest in economic issues [20] by understanding the meaning and usefulness of knowledge, while achieving an intuitive relational understanding [13] of the different economic phenomena present in theories and models[27,].

The use of games and experimental economics are expanding significantly as alternative strategies for teaching economics, prioritizing experiences that bring students closer to the economic mechanisms and reasoning, while making them more proactive [16].

Gamification is focused on challenges, rewards, achievements, among others, in a particular classroom environment with the particular elements required for the game, 
unlike Game-Based Learning (GBL) that focuses on the use of computer or digital environments [18], in which the use of gamification has positive effects [28, 29].

The simulation of markets, decision making and pricing, in addition to being a topic that facilitates the use of gamification, enables students to achieve a better understanding of competitive markets in the framework of environments that simulate the various market structures with changing assumptions and restrictions that can become a great challenge for teachers and students [28].

\subsection{Introductory moment. Emerco: A strategic pedagogical about markets}

Strategy and Markets in Economics - EMERCO is the pedagogical strategy designed to develop gamification in the classroom. It incorporates game elements to simulate a market of goods in which different agents interact to achieve their objectives. The agents are divided into groups that make decisions and/or carry out buying/selling strategies of the available products, basing their decisions on the available information in the market and the restrictions imposed by the rules of the game in order to gain as many points as possible.

The objective of the strategy is to simulate the dynamics present in a market scenario in which multiple agents make independent decisions according to the available information.

The strategy incorporates the participation of six teams whose members play the following roles:

a) The State: who collects taxes and imposes sanctions. This role is assumed by the teacher. He/she is in charge of the Referees who assist in the control process.

b) Guarantor/Referee: one per team is in charge of monitoring and controlling the rules of the game.

c) Registrar: who is in charge of systematizing the results of each transaction in each round of the game, for which he has the results table format.

d) Sellers: two or three players are in charge of selling the assigned objects.

e) Buyers: only two players are responsible for buying the products according to the purchase objectives assigned to each team.

The teams have the materials (Figure 1) for the dynamics of the game, as well as the available goods (Figure 2).

Each group has a reference price table. The prices established for the products take into account production costs with a profit margin. Prices may vary according to the decisions of the members of each team during each round, including during the time of negotiation with each buyer from another team.

Each team has the same initial revenues. The amount of money in circulation guarantees the completion of transactions and negotiations with a wide margin; in the game, an amount of $\$ 1,840,000$ is allocated to each team.

The participants have to pay a one-time transaction tax set by the State, the payment of which is made at any time during the game. The amount of the tax can change each round and may vary. The tax represents the payment that has to be made by any agent for the transactions in the market. In the game, that operation works as a 
precision mechanism and restricts the amount of money circulating in the game. The first groups to pay receive a discount for early payment. This is an element of distraction, the money serve as the lubricant of the game, independently from the amount each team ends up with, it is not counted in the final scores.

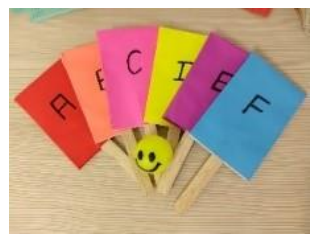

Auction paddles

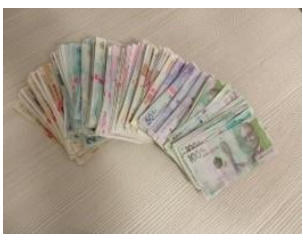

Didactic money

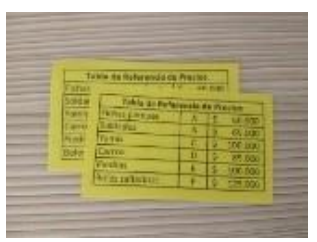

Reference Prices tables

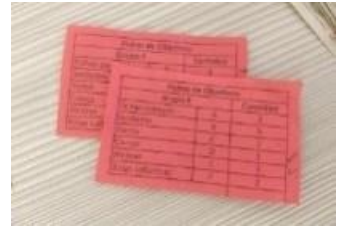

Table of goals

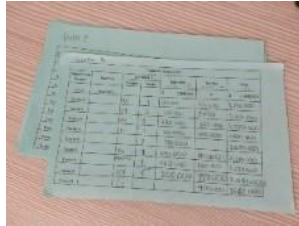

Results table

Fig. 1. Materials used in EMERCO

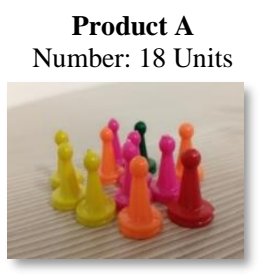

Product D

Number: 4 Units

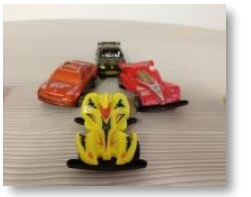

Product B

Number: 24 Units

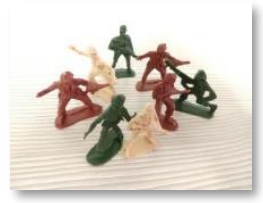

Product E

Number: 20 Units

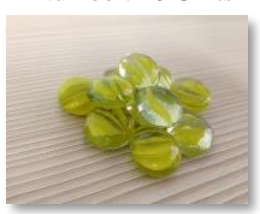

Product C Number: 10 Units

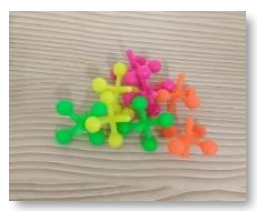

Product F Number: 6 Units

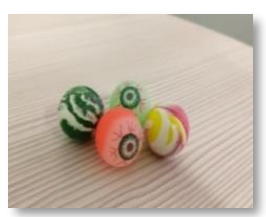

Fig. 2. Goods for purchase and sale in EMERCO

The game begins with an auction of a unique object in the game that represents the possibility of starting with a relative advantage in the game, since it adds up to twenty points. To do so, the teams use the paddle assigned to each group to make the bid. The auction ends when thirty seconds after a bid, another is not made; in that case, the auction closes and assigns the object to the last group with the raised paddle, who 
pays the value offered to the State. All the students have a maximum of five minutes for this process.

\section{Happy face}

Number: 1 units

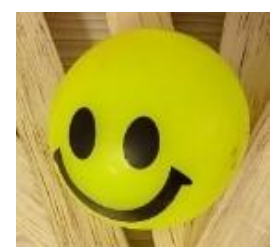

Fig. 3. Product auctioned in EMERCO

After the auction, each team can send a player to check the available number of items for sale from the other teams in the game. From then on, they have three minutes to define the strategy to be used.

Each team will have an allocation of purchase objectives which are given to them in an objectives card at the start of the game; this card is only seen by the members of their own groups. The purchase objectives are those necessary for the team to consolidate its consumption needs; however, the game is designed with restrictions since the possibility of meeting the objectives is limited, as the number of some products available in the market is lower than the total of the objectives of all the teams.

Table 1. Purchase objecives for each team in EMERCO

\begin{tabular}{|c|c|c|c|c|c|c|c|c|c|c|}
\hline \multicolumn{11}{|c|}{ Objectives } \\
\hline Letter & Product & \begin{tabular}{|c|} 
Group \\
\end{tabular} & $\begin{array}{c}\text { Group } \\
B \\
\end{array}$ & \begin{tabular}{|c|} 
Group \\
$C$
\end{tabular} & $\begin{array}{c}\text { Group } \\
D\end{array}$ & $\begin{array}{c}\text { Group } \\
E\end{array}$ & $\begin{array}{c}\text { Group } \\
\text { F } \\
\end{array}$ & $\begin{array}{c}\text { Total } \\
\text { objectives }\end{array}$ & $\begin{array}{c}\text { Available in } \\
\text { the market }\end{array}$ & Difference \\
\hline A & Park pieces & 3 & 3 & 3 & 3 & 3 & 3 & 18 & 18 & 0 \\
\hline B & soldiers & 5 & 4 & 4 & 4 & 5 & 4 & 26 & 24 & 2 \\
\hline $\mathrm{C}$ & $\begin{array}{l}\text { Jacks } \\
\text { pieces }\end{array}$ & 2 & 2 & 2 & 2 & 2 & 2 & 12 & 10 & 2 \\
\hline D & Cars & 1 & 1 & 1 & 1 & 1 & 1 & 6 & 4 & 2 \\
\hline $\mathrm{E}$ & Stones & 3 & 4 & 4 & 3 & 3 & 3 & 20 & 20 & 0 \\
\hline $\mathrm{F}$ & $\begin{array}{l}\text { Jumping } \\
\text { bags }\end{array}$ & 2 & 2 & 2 & 2 & 2 & 2 & 12 & 6 & 6 \\
\hline
\end{tabular}

Source: own elaboration

The maximum number of rounds to play during the game is nine. Each round lasts two minutes. During that time, the buyers of each team can go to the different sales tables and make the permitted transactions. The buyers must bring the amount of money they think they will use; they cannot owe money to any team. If in any transaction the buyer is short of money, he/she must return to his/her table and complete it. During each round, only one buyer from each team can be at a sales table and buy no more than the number listed in Table 2. That ensures that all teams have access to the products according to the priorities established in their purchasing strategy according to the objectives they have to achieve. 
Table 2. Maximum purchase quantities for each team in each round in EMERCO

\begin{tabular}{|l|c|c|}
\hline \multicolumn{1}{|c|}{ Letter } & Object & Maximum number per round \\
\hline A & Park pieces & 2 \\
\hline B & soldiers & 3 \\
\hline C & Jacks pieces & 1 \\
\hline D & Cars & 1 \\
\hline E & Stones & 4 \\
\hline F & Jumping bags & 1 \\
\hline
\end{tabular}

Source: Own elaboration

After each round, the Registrar takes the corresponding notes in the results table of the sold products, purchased products and the cash flow of each made transaction. This process is important in order to corroborate the money that each group will have at the end and to follow the dynamics of the movements.

The possible scores for meeting the purchase objectives are shown in Table 3. Each team can reach a maximum of 200 points if they manage to meet the assigned objectives and win the auction. Points are assigned proportionally to the number of items that each team manages to purchase, according to their purchase objectives; however, no additional points are assigned if they end up with more products than assigned, in order to avoid product hoarding.

Table 3. Scores for achieving the objectives in EMERCO

\begin{tabular}{|l|c|c|}
\hline \multicolumn{1}{|c|}{ Letter } & Objective & Score \\
\hline A & Park pieces & 20 \\
\hline B & Soldiers & 30 \\
\hline C & Jacks pieces & 30 \\
\hline D & Cars & 30 \\
\hline E & stones & 20 \\
\hline F & Jumping bags & 50 \\
\hline Auction & Happy face & 20 \\
\hline
\end{tabular}

Source: Own elaboration

Any infraction of the rules of the game is sanctioned with money, in an amount fixed at the beginning of the game, which will be used to pay to the State. In this regard, the Referees play an important role since they are in charge of assisting in the supervision process.

At the end of all the rounds, the team that achieves the most points according to the achieved objectives wins.

Gamification elements of a pedagogical proposal. According to Oliva [20], a strictly gamified pedagogical action has game elements/components, game mechanics and game dynamics. The elements are the particular aspects that are taken from a game to bring them to a non-game scenario; in the case of gamification, they are used with pedagogical intentions. Table 4 shows a list of the different elements that can be brought from a game. In regard to EMERCO, these are the elements: 
- Equipment: auction paddles, didactic money, board formats and products.

- Teams: this is a fundamental part of the dynamics proposed for the game, which allows the development of teamwork.

- Personalization: each participant has a defined role at the beginning of the game (the registrar, the referee, the seller or buyer)

- Absolute ranking: the game ends with a ranking ordered from the highest to the lowest score, this ranking is fixed once the game ends.

- Commerce system: the game simulates the operation of a goods market where transactions are carried out.

Table 4. Usable elements of a game

\begin{tabular}{|l|l|l|l|l|}
\hline Levels & Relative Ranking & XP & Social area & Personalization \\
\hline Equipement & Fixed rewards & Avatar & Teams & Guilds/clans \\
\hline Medals & Social Ranking & Virtual currency & Epic challenge & Access item \\
\hline Abilities & Group rewards & Power up! & Duels & Absolute Ranking \\
\hline Search & World & Special events & Tutorial & Commerce system \\
\hline Aleatory rewards & Embassors & Easter eggs & Lifeguard & \\
\hline
\end{tabular}

Source: [27]

EMERCO has four dynamics that reflect the game mechanics: competing, to achieve the purchase objectives; identifying strategies to carry out transactions and achieve the purchase objectives; buying to achieve the purchase objectives; and, selling the product they are in charge of.

Table 5. Game mechanics

\begin{tabular}{|l|c|c|}
\hline \multicolumn{1}{|c|}{ What do I want them to do? } & How? & By what? \\
\hline Share & Finding & Helping \\
\hline Colect & Identifying & Commenting \\
\hline Compete & Cooperating & Designing \\
\hline Complete & Building & Choosing \\
\hline Destroy & Putting in order (disorder) & Exploring \\
\hline Ask & Descovering & Buying \\
\hline Modify & Inquiring & Selling \\
\hline Hide & Cutting & Swapping \\
\hline Hit & Remembering & \\
\hline Challenge & Comparing & \\
\hline
\end{tabular}

Source:[27]

As proposed by Pedraz [31], the dynamics reflect the forms of participation and relationships in the game, which refer to the behaviors and/or expected behaviors in the participation in the game (Table 6). In the case of EMERCO, two dynamics are expected: integration, as it gathers students to share as a team in a dynamic and active way, and participation, as it encourages students to assume a specific role and contribute ideas to the particular game strategies. 
Table 6. Dynamics for gamification

\begin{tabular}{|l|l|}
\hline Socialization & Integration \\
\hline Argumentation & Acceptance \\
\hline Debate & Attention \\
\hline Participation & Physical activity \\
\hline Status & Active listening \\
\hline Reflection & \\
\hline Source:
\end{tabular}

The basic elements to consider a class gamified are analyzed in Table 7 [20].

Table 7. Analysis of the gamification elements in the EMERCO game

\begin{tabular}{|l|l|}
\hline \multicolumn{1}{|c|}{ Elements of a gamified class } & \multicolumn{1}{c|}{ EMERCO } \\
\hline $\begin{array}{l}\text { Gamifying dynamic } \\
\text { Includes game elements in the class }\end{array}$ & $\begin{array}{l}\text { EMERCO takes elements such as equipment, teams, } \\
\text { personalization, ranking and commerce system from } \\
\text { games. }\end{array}$ \\
\hline $\begin{array}{l}\text { Score } \\
\text { Assign values based on the difficulty or complexity } \\
\text { of the challenge presented }\end{array}$ & $\begin{array}{l}\text { Meeting the purchase objectives helps to gain points } \\
\text { which are proportional to the achieved amount. }\end{array}$ \\
\hline $\begin{array}{l}\text { Levels } \\
\text { They are related to progress or regression in regard } \\
\text { to a specific learning action. }\end{array}$ & $\begin{array}{l}\text { Each round establishes an increasing level of com- } \\
\text { plexity in terms of negotiation efforts and the use of } \\
\text { more money to achieve the objectives. }\end{array}$ \\
\hline $\begin{array}{l}\text { Stimuli } \\
\text { They are needed in view of the achievement of } \\
\text { specific objectives or indicators of achievement }\end{array}$ & $\begin{array}{l}\text { As an incentive, decimal points are assigned, which } \\
\text { are added to the course evaluation, according to the } \\
\text { final ranking of scores. All students gain at least one } \\
\text { decimal for participating and the winning team has a } \\
\text { higher incentive. }\end{array}$ \\
\hline $\begin{array}{l}\text { Intention } \\
\text { It is based on gotten points or achieved objectives }\end{array}$ & $\begin{array}{l}\text { The game combines the achievement of purchase } \\
\text { objectives through the strategies defined by each team } \\
\text { and the accumulation of points in the process. }\end{array}$ \\
\hline $\begin{array}{l}\text { Challenge } \\
\text { Constant competition among peers }\end{array}$ & $\begin{array}{l}\text { The game focuses on competition among students to } \\
\text { achieve assigned goals. }\end{array}$ \\
\hline $\begin{array}{l}\text { Role } \\
\text { Mission or challenge that represents a difficulty to } \\
\text { overcome. }\end{array}$ & $\begin{array}{l}\text { Students have restrictions for the achievement of the } \\
\text { mission in terms of achievable transactions, for which } \\
\text { they must play a role defined by the team. }\end{array}$ \\
\hline Source: Adapted and own ins
\end{tabular}

Source: Adapted and own interpretation based on elements proposed by Oliva [20].

Consequently, EMERCO can be defined in the gamification framework as a learning strategy. The use of similar strategies is demonstrated in the literature on economic education; however, this game has differences in structure, as most of related games work with markets using decks of cards as well as products and money, while EMERCO uses tangible products and didactic money, achieving a simulation which can be closer to real transactions.

The way in which the teams operate also represents variations from other games that assume the roles of buyers and sellers separately, while, in EMERCO, each team plays both roles simultaneously. 


\subsection{Moment of experimental results and validation of EMERCO}

The game can be summarized in three phases that have served as exploration and improvement, applied in undergraduate programs.

The first phase dates from the first academic period in the Fundamentals of Economics courses in the Tourism Program, where students had difficulty in understanding the economic models and the logic of economics. This first approach suggests the need to search for alternatives for future courses.

The second phase corresponds to a later academic period, where clues about alternative strategies are consolidated as a result of the formative process in university educational innovations, among them, the approach to gamification in the classroom and the use of games as a teaching strategy.

The above permitted the ideation of a pilot market game for courses such as Economic Theory and Colombian Economy (Teoría Económica y Economía Colombiana, TEC) in the Law program. This pilot did not contemplate the definition of roles per student, nor the role of the referee, and the tax was a constant value throughout the game.

This pilot A evidenced fierce and restrictive competition strategies, because the strategies of one group included selling the products at exorbitant prices and not selling the product to limit the possibilities of the other groups. As a result, the group suffered punishment from the rest of the groups that assumed the same position and it put them last in the ranking.

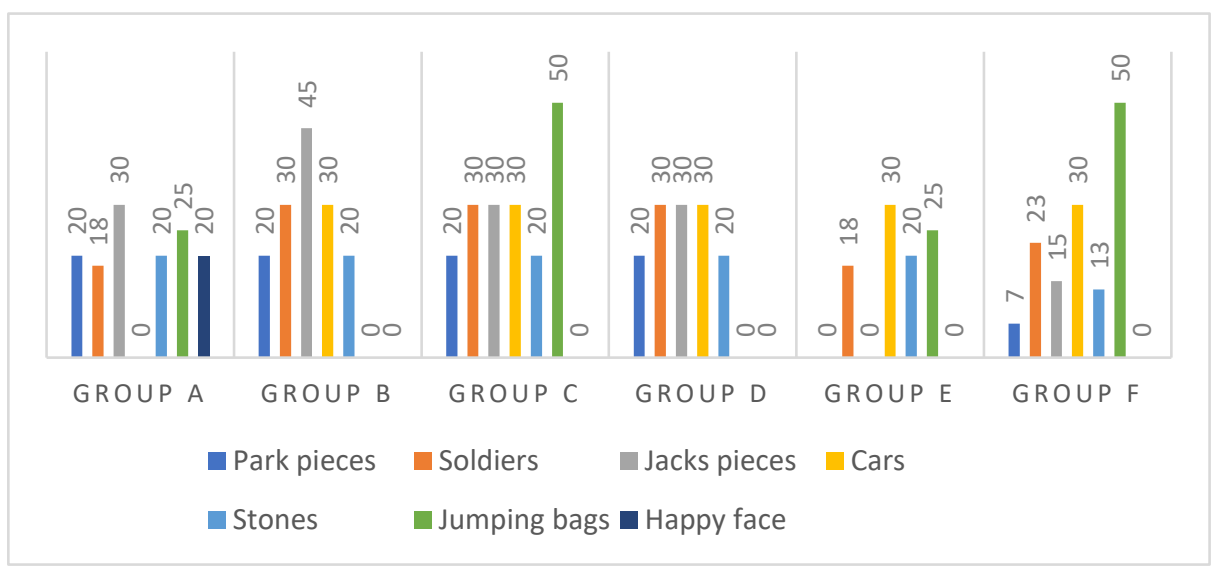

Fig. 4. Scores by accomplished objectives - Pilot A

Group $\mathrm{C}$ got the first place by achieving all the purchase objectives, but did not get the auction product, which was purchased by Group A for $\$ 150,000$. 


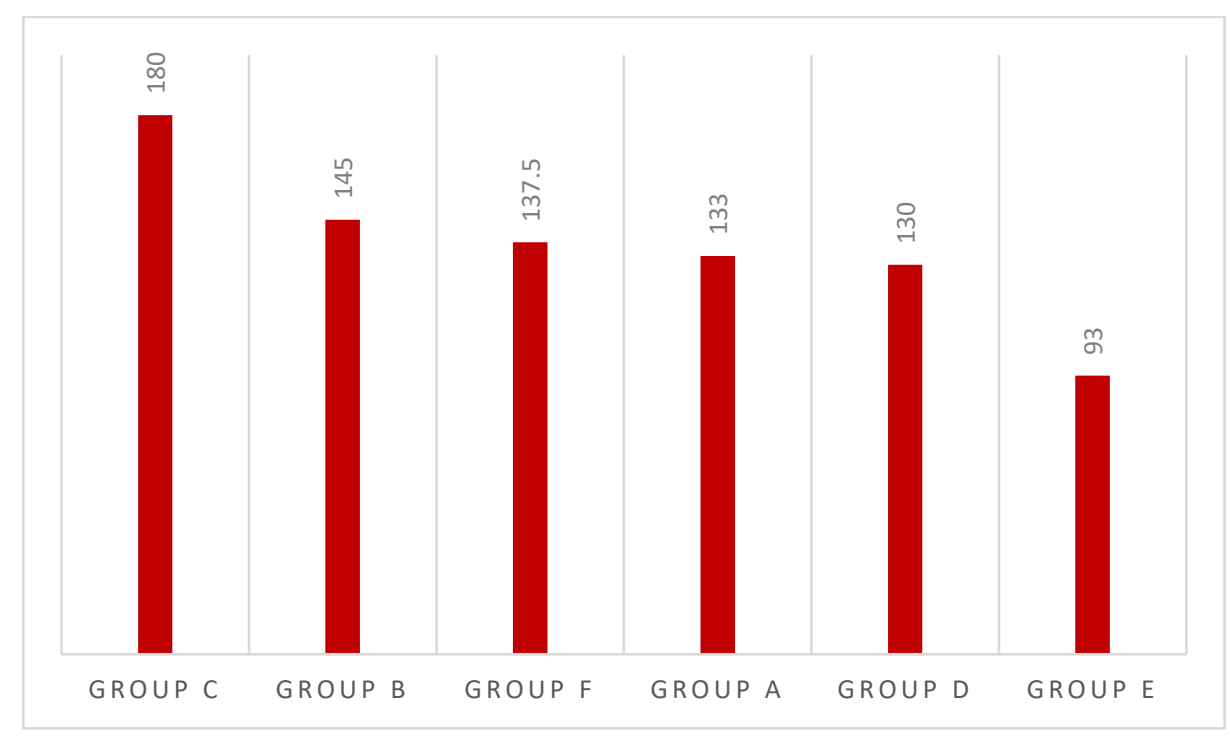

Fig. 5. Ranking of final scores - Pilot A

Pilot B worked according to plan, the groups negotiated within the framework of the strategies prioritized by each team, who did not generate restrictive strategies with respect to the rest of the groups, and, in general, the environment was cordial.

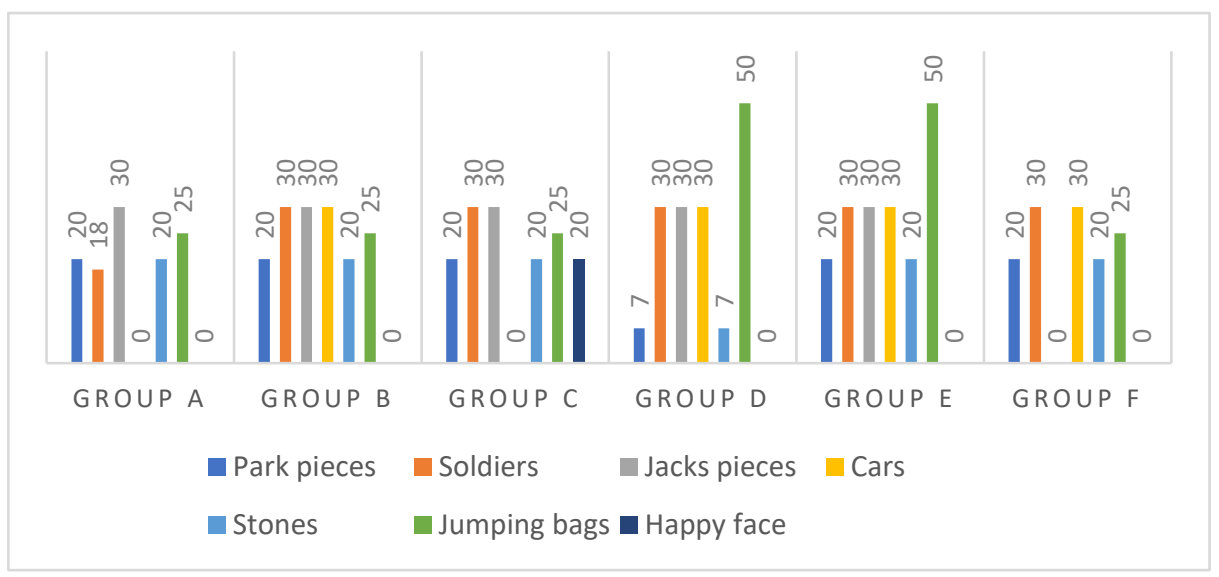

Fig. 6. Ranking of final scores - Pilot B

Group E won the first place by achieving all the purchase objectives, Group C won the auction with the price of $\$ 95,000$. 


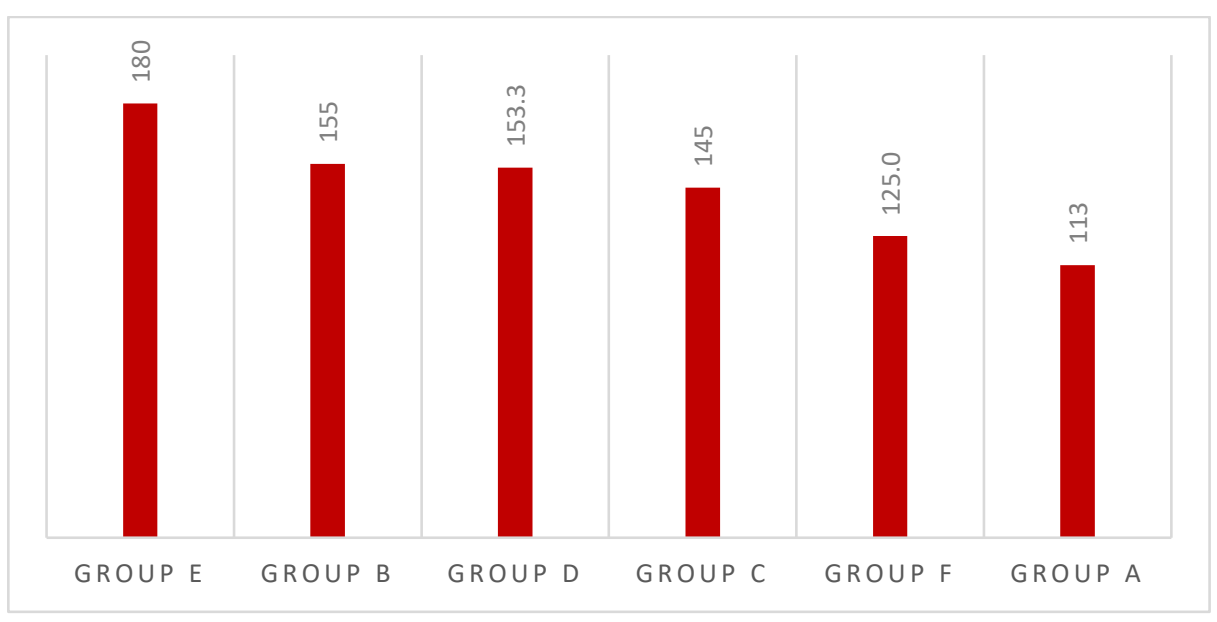

Fig. 7. Ranking of final scores - Pilot B

The third phase corresponds to the process carried out with students of the Political Science program (IE-CIPOL) in the Introduction to Economics class. The distribution of the teams had a significant change by incorporating a test based on the principles of the Herman Brain Dominance Instrument [32] that explains the thinking and creation process of an individual.

That tool allows us to classify the type of brain dominance (Table 8) and is frequently used to form teams with different types of skills and mentalities.

Table 8. Brain quadrants

\begin{tabular}{|l|l|}
\hline 1. Left cerebral cortex $(\boldsymbol{A})$ & 2. Right cerebral cortex $(\boldsymbol{D})$ \\
\hline $\begin{array}{l}\text { The expert } \\
\text { Logical-analytical } \\
\text { Based on facts, quantitative } \\
\text { Realist }\end{array}$ & $\begin{array}{l}\text { The strategist } \\
\text { Holistic - intuitive } \\
\text { Synthesizing-integrating } \\
\text { Idealist }\end{array}$ \\
\hline 3. Left limbic $(\boldsymbol{B})$ & 4. Right limbic $(\boldsymbol{C})$ \\
\hline $\begin{array}{l}\text { Organized } \\
\text { Sequential } \\
\text { Planned, detailed }\end{array}$ & $\begin{array}{l}\text { The communicator } \\
\text { Interpersonal, feelings }\end{array}$ \\
\hline
\end{tabular}

Source: [33]

The adaptation of the test was carried out with a questionnaire of eight questions that inquire about the preferred activities in childhood, school, performance and leisure activities, as well as the description of qualities, motivations in particular situations, reactions in particular situations and convictions.

The test was systematized and yields a star graph that classifies the students according to the type of brain dominance (Figure 8). 


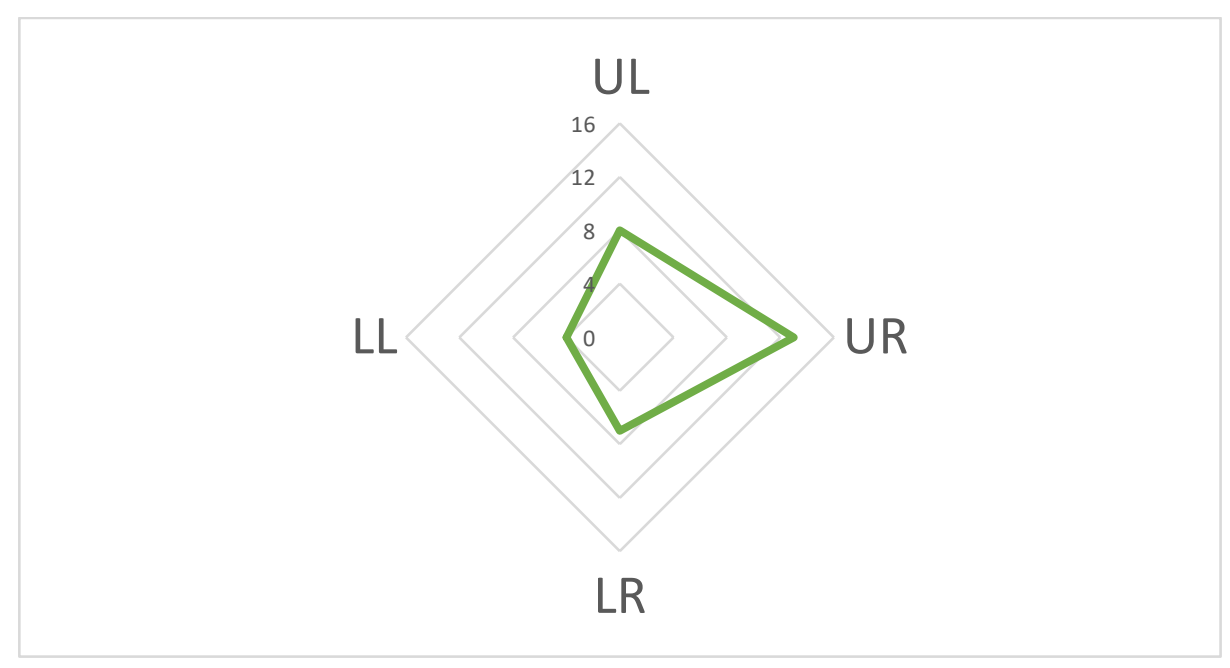

Fig. 8. Example of a star diagram on brain dominance

The classification of the student body took into account the type of mentality defined by specific profiles as a result of the type of brain dominance, based on the typology shown in Figure 9.

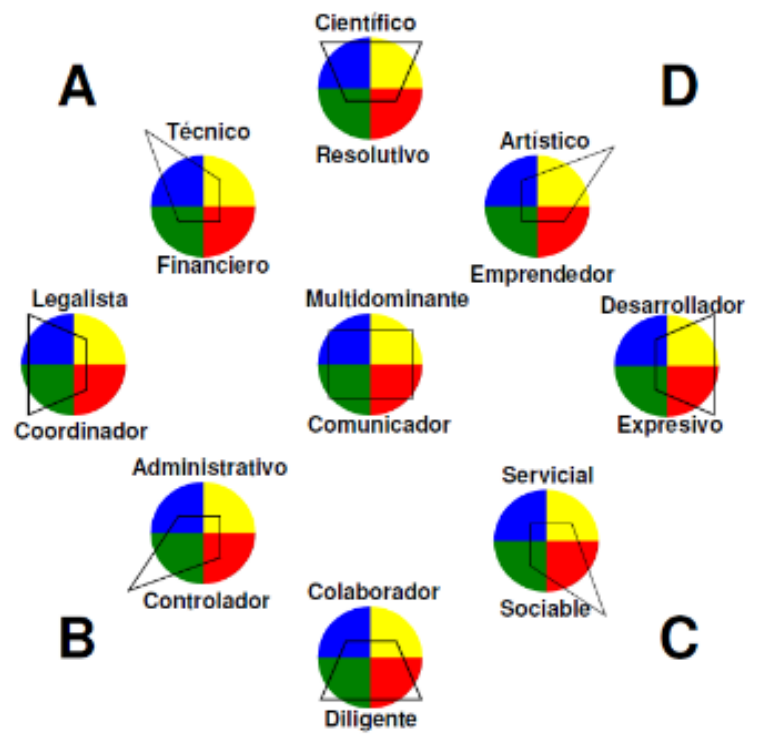

Fig. 9. Types of mentality according to the profiles

As a result, we found the existence of all the types of mentality in the course. The highest preponderance was in four types: controlling, diligent, financial and entrepreneurial, while the expressive type had the lowest proportion. 
Table 9. Groups of students by mentality type in IE-CIPOL Class

\begin{tabular}{|l|c|c|c|c|c|c|}
\hline \multicolumn{1}{|c|}{ Mentality } & Group A & Group B & Group C & Group D & Group E & Group F \\
\hline Manager/controlling & 1 & 2 & 2 & 2 & 2 & 2 \\
\hline Artistic/entrepreneurial & & 1 & 1 & 1 & 1 & 1 \\
\hline Scientific/problem solver & & & 1 & 1 & & \\
\hline Cooperative/diligent & 1 & 1 & 1 & 1 & 1 & 1 \\
\hline Communicative & 1 & & & & & 1 \\
\hline Developer/expressive & 1 & & & & & \\
\hline Legalistic/coordinating & & 1 & & & 1 & 1 \\
\hline Helpful/sociable & 2 & & & & & \\
\hline Technical/financial & 1 & 1 & 1 & 1 & 1 & 1 \\
\hline Total & $\mathbf{7}$ & $\mathbf{6}$ & $\mathbf{6}$ & $\mathbf{6}$ & $\mathbf{6}$ & $\mathbf{7}$ \\
\hline
\end{tabular}

Source: Own elaboration

The results in this class showed that the final scores changed according to the strategies of each group and the game could be won by any group depending on their decisions. In this case, Group D obtained the lowest result of the game; considering the perceptions of the group and relating the type of mentalities, it is evident that they chose a member of the team with an artistic profile to carry out the negotiations of the purchases, since he did not manage to finalize any negotiation in the time that was established in each round.

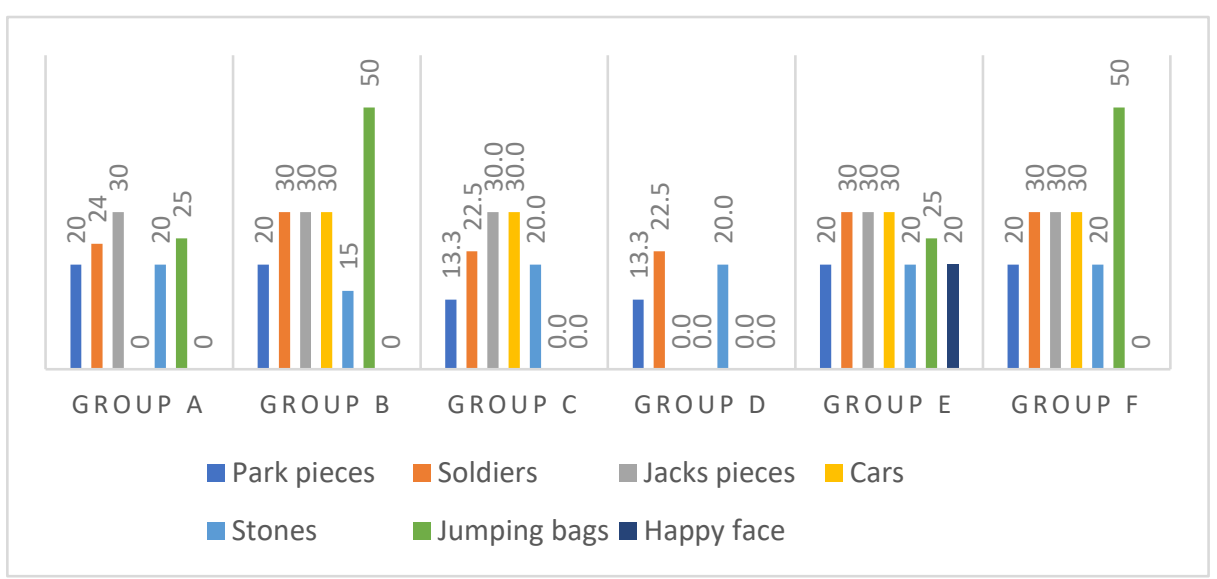

Fig. 10.Scores by Achieved Objectives - IE-CIPOL Class - Group A

In this section, Group $\mathrm{F}$ achieved 180 points and Group E won the auction with the price of $\$ 306,000$. 


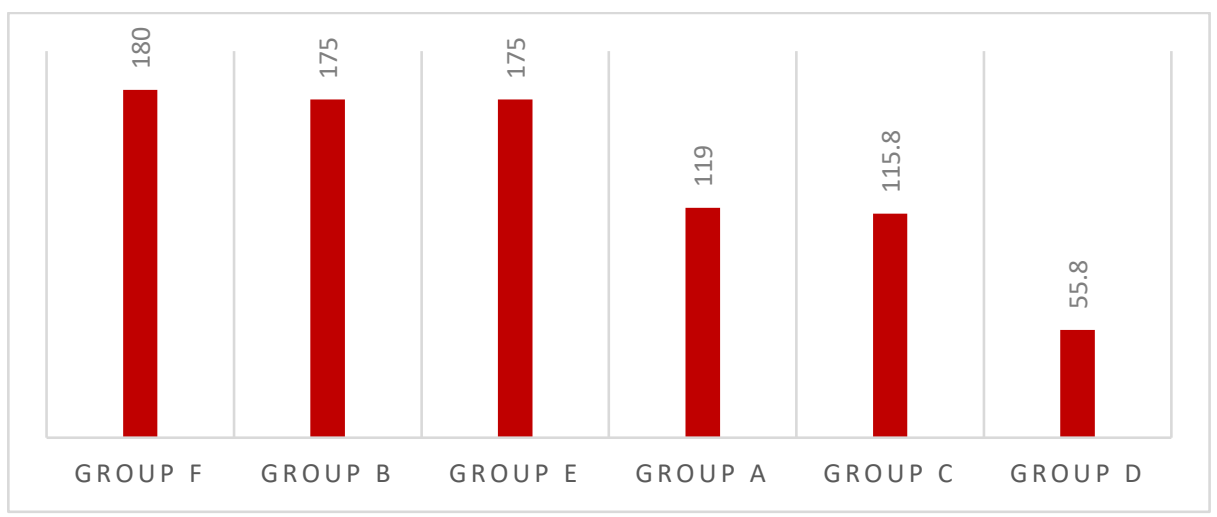

Fig. 11.Ranking of final scores - IE-CIPOL Class - Group A -V1

This same group of students repeated the game to validate the changes in the behavior of strategies, taking into account the experience in the previous process, the negotiation dynamics changed, a higher bid was made in the auction, greater restrictions were generated, raising prices and/or refusing the sale of some products, which resulted in lower scores with respect to the previous version of the game.

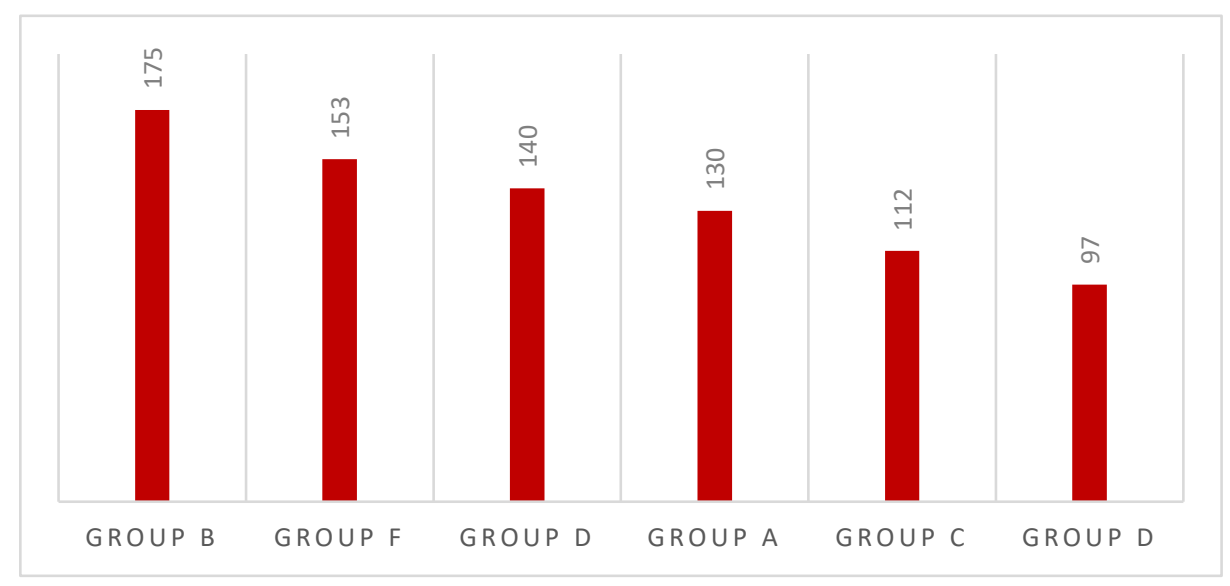

Fig. 12.Ranking of Final Scores - Class IE-CIPOL - Group A -V2

In this repetition, Group B achieved 175 points and won the auction with a price of $\$ 500,000$, the highest amount paid for that product.

Finally, the same parameters of the game were applied to a new group of Political Science students, taking into account the division of groups due to the administration of the test. The negotiation processes were carried out as expected, Group D obtained the lowest result of the game. 


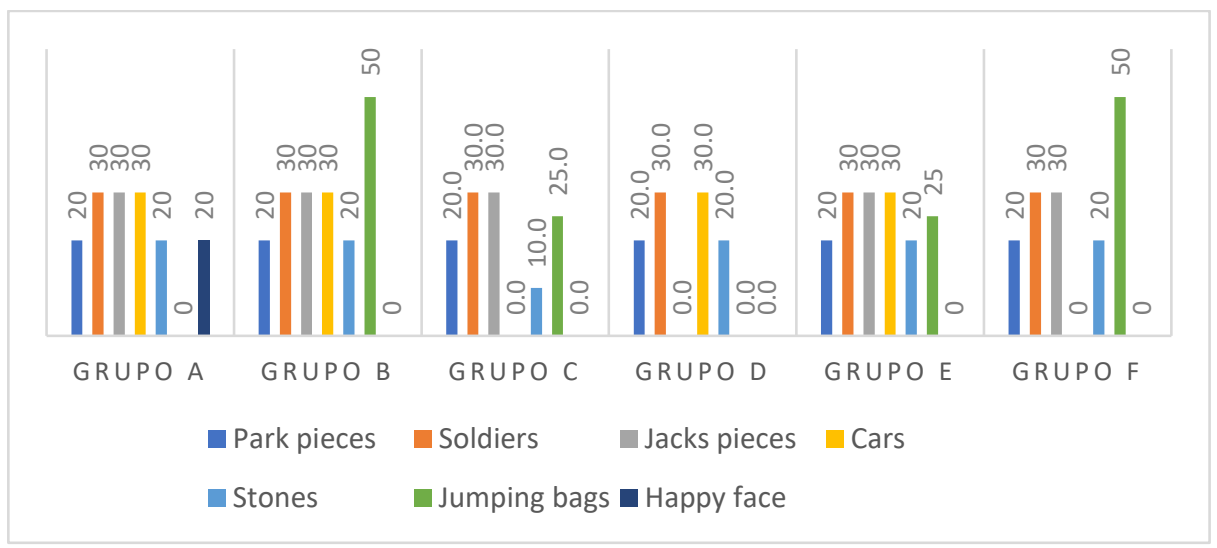

Fig. 13.Scores by achieved objectives - Class IE-CIPOL- Group B

In this section, Group B achieved 180 points and Group A won the auction with a price of $\$ 352,000$.

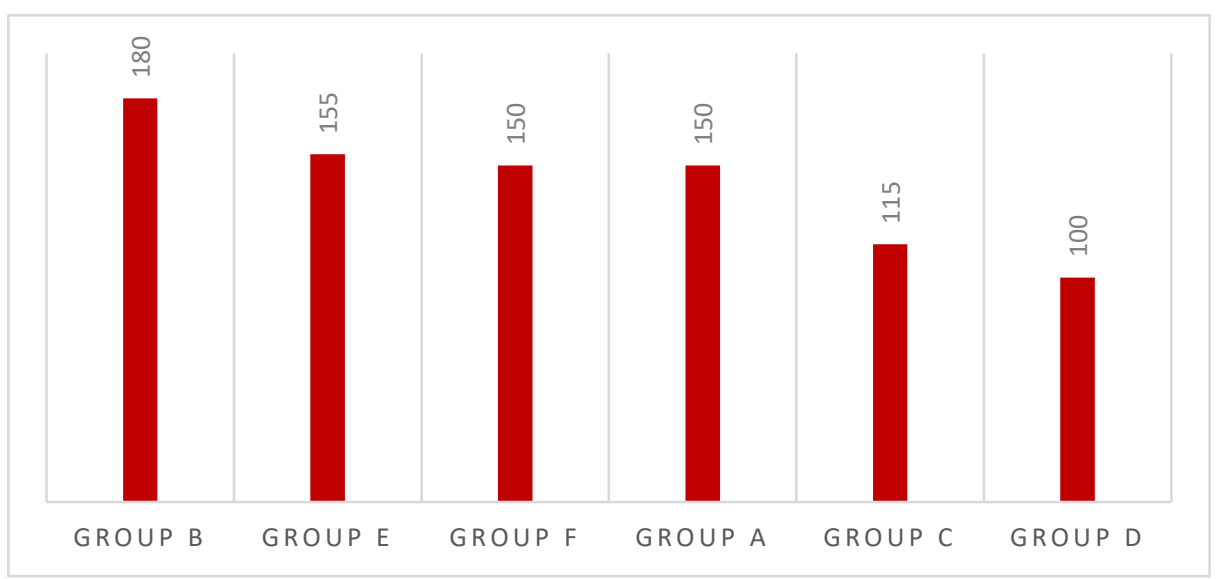

Fig. 14.Ranking of Final Scores - Class IE-CIPOL - Group B

It is important to mention that the game is still in the validation phase. It requires additional explorations of the dynamics of the repeated game with the same team, forming groups with similar mentalities, applying it to economics students, among others, in order to explore possibilities and make the pertinent adjustments to the proposed methodology. 


\section{Perceptions and considerations on the application of the game}

After each section of the game, there was feedback in two ways. On the one hand, to evidence perceptions on the application of the game and, on the other hand, to explore the extent of assimilation of the concepts on the functioning of the market.

In general terms, the students' perceptions about the game are positive. The game enables greater participation and dynamics in the classroom; it directs group discussions to the strategies to be proposed, encourages a collaborative spirit within the teams and among them, and is fun and exciting while learning.

In addition, it became evident that the payment of taxes and fines provoked negative reactions, resistance to accept compliance with the rules and postponement of the payment of taxes until the last rounds. This is an element that requires further exploration.

In summary, the game allows students to achieve a greater assimilation of the functioning of the market, the role of economic agents and the understanding of the law of supply and demand. In accordance with the above, the average grade improved in comparison with a purely traditional class without a gamification strategy (Table 10). That is, when comparing the Tourism group with the rest of the groups in which both strategies were introduced, we can see the improvement of the grades.

Table 10. Average class grades

\begin{tabular}{|l|c|}
\hline \multicolumn{1}{|c|}{ Program } & Final \\
\hline Tourism & 2,6 \\
\hline Law - A & 3,8 \\
\hline Law - B & 3 \\
\hline CIPOL - A & 3,7 \\
\hline CIPOL - B & 3,8 \\
\hline
\end{tabular}

Source: Own elaboration

In order to verify if there were significant changes in the results of the grades with the introduction of the learning strategy, the results of the 135 students who participated in two moments were compared. For each of the four groups in which the game was applied, we performed a cut-off of grades which were evaluated using traditional strategies, and a second cut-off with the introduction of the gamification elements with the EMERCO game, to compare the results with the same students.

To make these comparisons at the statistical level, we proceeded to test normality of the difference of the grades in the cut-off points, using the Kolmogorov-Smirnov test because it is a sample with more than 50 data, and the following working hypotheses are defined:

H0: Homogeneity in the variables

H1: Difference in the variables 
Table 11. Normality test of the variables

\begin{tabular}{|l|c|c|c|}
\hline & \multicolumn{3}{|c|}{ Kolmogorov-Smirnov a $^{\text {a }}$} \\
\hline & Statistical test & $\boldsymbol{g l}$ & Sig. \\
\hline Dif &, 071 & 134 &, 094 \\
\hline
\end{tabular}

Source: Own elaboration with SPSS software

As the p-value (sig) is higher than 5\%, the null hypothesis is accepted, so the variables follow a normal distribution. In this sense, it is necessary to use parametric tests, in this case, Student's t-test for related samples, with the following hypotheses:

H0: $\underline{X_{D}}=0-$ There are no differences between the final and initial cut - off grades.

H1: $\underline{X}_{D} \neq 0-Y e s$, there are differences between the final and initial cutoff grades.

Table 12. $\quad T$ test for means of two related samples for grades

\begin{tabular}{|c|c|c|c|c|c|c|c|c|}
\hline & \multicolumn{5}{|c|}{ Related differences } & \multirow{3}{*}{$t$} & \multirow{3}{*}{$g l$} & \multirow{3}{*}{$\begin{array}{l}\text { Sig. } \\
\text { (two- } \\
\text { tailed) }\end{array}$} \\
\hline & \multirow[t]{2}{*}{ Mean } & \multirow[t]{2}{*}{$\begin{array}{l}\text { Standard } \\
\text { deviation }\end{array}$} & \multirow{2}{*}{$\begin{array}{l}\text { standard } \\
\text { error of } \\
\text { the mean }\end{array}$} & \multicolumn{2}{|c|}{$\begin{array}{c}95 \% \text { confidence } \\
\text { interval for the } \\
\text { difference }\end{array}$} & & & \\
\hline & & & & $\min$ & $\max$ & & & \\
\hline $\begin{array}{l}\text { Pair 1 final } \\
\text { cut-off - } \\
\text { initial cut-off }\end{array}$ & 0.23659 & 0.8212 & 0.7068 & 0.0968 & 0.37638 & 3.347 & 134 & 0.001 \\
\hline
\end{tabular}

Source: Own elaboration with SPSS software

According to the result, it is observed that the p-value (sig) is lower than 5\%, so the null hypothesis is rejected and the alternative hypothesis is accepted, which implies that there is a positive and statistically significant difference between the results of the scores of the cut-off where the gamification strategy is proposed and the cut-off where the traditional strategy is proposed.

\section{Conclusions}

The teaching of economics has had significant challenges worldwide recently, which are evident in introductory and fundamentals of economics courses in university students majoring careers which are not economics, particularly with regard to the ease of the understanding of the mechanism and logic of economic phenomena and their instrumentalization.

Therefore, this study shows, at an exploratory level, that it is possible to obtain greater assimilation of concepts related to the study of the market as a relevant category for the understanding of economic models. This could be achieved through changes in the pedagogical mediation strategies used for the teaching of economics.

Strategies based on gamification are studied in the literature related to economic education as an alternative that shows satisfactory results to increase participation and involve students in the process of self-learning.

The use of Strategies and Markets in Economics - EMERCO performs a market simulation, involving economic agents defined by the roles assumed by the students. 
In spite of being in the process of validation, it manages to improve topics comprehension and grades in the courses where it was implemented, presenting statistically significant results.

Finally, the results of the game are mediated with the type of mentality and brain dominance of the members of the teams, which may be associated with the vocational profiles in regard to the disciplines where the game has been developed.

\section{$5 \quad$ Acknowledgment}

This article is the result of the research project ID-4664 "Academic, pedagogical and communication strategies aimed at positioning the Economics program of the Universidad del Cauca" financed by the XII Call for I + D + i projects Vice-rector's Office for Research - Universidad del Cauca

\section{$6 \quad$ References}

[1] Rosenmann, M. R. (2012). Los indignados: el rescate de la política (Vol. 14). Ediciones Akal.

[2] Martínez-Usarralde, M. J., Lloret-Catalá, C., \& Mas-Gil, S. (2017). University Social Responsibility (USR): Principles for a sustainable, cooperative and democratic university from the participative diagnosis of its student body. education policy analysis archives, 25 , 75. https://doi.org/10.14507/epaa.25.2769

[3] Cabal, F. (Ed.). (2011). Indignados! 15-M. Ediciones Mandala.

[4] Andrade, R. (2015). La formación humana como dinamismo esencial hacia la plenitud del ser. Revista Colombiana De Bioética, 8(2), 87-103. https://doi.org/10.18270/rcb.v8i2.795

[5] Cruickshank, D., \& Telfer, R. (1980). Classroom Games and Simulations. Theory Into Practice, 19(1), 75-80. Retrieved February 16, 2021, from http://www.jstor.org/stable/ 1476290. https://doi.org/10.1080/00405848009542875

[6] McCormick, T. (2013). Anthropology of an idea: gamification. Foreign Policy, (201), 2627. Retrieved February 16, 2021, from http://www.jstor.org/stable/24575963

[7] Gaitán Riveros, C. A. (2019). Docencia e investigación en la Universidad. En Curso de Docencia Universitaria - Universidad del Cauca. Popayán. https://doi.org/10.18273 /revsal.v50n1-2018006

[8] Guin-Po, A., \& Vidal, M. (2015). Enseñanza de la economía en la Pontificia Universidad Católica de Chile: Un análisis comparativo. Estudios nueva economía, 4(1), 47-55. https://doi.org/10.4067/s0717-68212006000200005

[9] Jordán, D. R. (2003). La enseñanza de la economía: algunas reflexiones sobre la metodología y el control de la actividad docente. Instituto de Estudios Fiscales. https://doi.org /10.24965/da.v0i1.10166

[10] López Navarro, C. (2013). La gamificación en el Área de Economía.

[11] Fuentes Hurtado, Mercedes; González Martínez, Juan. Necesidades formativas del profesorado de Secundaria para la implementación de experiencias gamificadas en STEM RED. Revista de Educación a Distancia, núm. 54, junio, 2017, pp. 1-25 Universidad de Murcia, España. Disponible en: https://www.redalyc.org/pdf/547/54751771008.pdf. https://doi.org/ $\underline{10.6018 / \mathrm{red} / 54 / 8}$ 
[12] Hierro Recio, L., Atienza Montero, P., \& Pérez Díez de los Rios, J. (2014). Una experiencia de aprendizaje universitario mediante juegos de torneo en clase. REDU. Revista de Docencia Universitaria, 12(4), 415-436. https://doi.org/10.4995/redu.2014.5634

[13] Palacio, L. A., Saravia, I., \& Vesga, M. A. (2017). Juegos en el salón de clase. El mercado de los limones. Revista de economía institucional, 19(36), 291-311. Recuperado de https://doi.org/10.18601/01245996.v19n36.11

[14] Lacleta, M. L. S. E., Blanco, Á. F., \& Peñalvo, F. J. G. (2014). Buenas prácticas de Innovación Educativa: Artículos seleccionados del II Congreso Internacional sobre Aprendizaje, Innovación y Competitividad, CINAIC 2013. Revista de Educación a Distancia (RED), (44). https://doi.org/10.26754/cinaic.2019.0127

[15] Villalba Ríos, P. y Aguilar Escobar, V. G. (2020). La gamificación como innovación metodológica. El uso del breakout educativo en la asignatura economía de bachillerato. In XXX Jornadas Luso-Espanholas de Gestão Científica: cooperação transfronteiriça: desenvolvimento e coesão territorial: livro de resumos (p. 183). Instituto Politécnico de Bragança. https://doi.org/10.2307/j.ctv103x9s5.10

[16] Rivera-lozada, I. C., Collazos-ardila, R., Rivera-lozada, O. (2021). Peacebuilding education, a complex perspective. Cogent Education, 8(1), 0-10. https://doi.org/10.1080/ $\underline{\text { 2331186x.2021.1905228 }}$

[17] Muñoz, J. C., Aparicio, S., \& Mesa Aristizábal, M. (2011). ¿Qué la economía no es un juego? Evidencia del uso de Economía Experimental en cursos de Introducción a la Economía. Ecos de economía, 15(33), 185-207. Recuperado de http://search.ebscohost.com /login.aspx ?direct=true \&db=fua\&AN=81283490\&lang=es\&site=ehost-live. https://doi.org/10.1016/s0210-0266(13)70038-4

[18] Holt, C. A. (1996). Classroom Games: Trading in a Pit Market. Journal of Economic Perspectives. https://doi.org/10.1257/jep.10.1.193

[19] Alsubhi, M. A., Sahari, N., \& Wook, T. T. (2020). A Conceptual Engagement Framework for Gamified E-Learning Platform Activities. International Journal of Emerging Technologies in Learning (iJET), 15(22), 4-23. https://doi.org/10.3991/ijet.v15i22.15443

[20] Oliva, H. A. (2017). La gamificación como estrategia metodológica en el contexto educativo universitario. Realidad y Reflexión, 16(44), 29. https://doi.org/10.5377/ryr.v44i0.3563

[21] Lozada-Ávila, C., \& Betancur-Gómez, S. (2017). La gamificación en la educación superior: una revisión sistemática. Revista Ingenierías Universidad de Medellín, 16(31), 97124. https://doi.org/10.22395/rium.v16n31a5

[22] Rodriguez, C. A. C. (2018). Gamificación en educación superior: experiencia innovadora para motivar estudiantes y dinamizar contenidos en el aula. Edutec. Revista Electrónica de Tecnología Educativa, (63), 29-41. https://doi.org/10.21556/edutec.2018.63.927

[23] Parra González, M. y Segura Robles, A. (2019). Producción científica sobre gamificación en educación: Un análisis cienciométrico. Revista de educación, (386), 113-136.

[24] Parente, D. (2016). Gamificación en la educación. Gamificación en aulas universitarias, 11.

[25] Prieto Andreu, J. M. (2020). Una revisión sistemática sobre gamificación, motivación y aprendizaje en universitarios. https://doi.org/10.14201/teri.20625

[26] Yamani, H. A. (2021). A Conceptual Framework for Integrating Gamification in eLearning Systems Based on Instructional Design Model. International Journal of Emerging Technologies in Learning, 16(4). https://doi.org/10.3991/ijet.v16i04.15693

[27] Contreras Espinosa, R. S. (2016). Presentación. Juegos digitales y gamificación aplicados en el ámbito de la educación. RIED: Revista Iberoamericana de Educación a Distancia, 19(2), 27-33. https://doi.org/10.5944/ried.19.2.16143 
[28] Aparicio, M., Oliveira, T., Bacao, F., \& Painho, M. (2019). Gamification: A key determinant of massive open online course (MOOC) success. INFORMATION I\& MANAGEMENT, 56(1), 39-54. https://doi.org/10.1016/j.im.2018.06.003

[29] Zabala-Vargas, S., García-Mora, L., Arciniegas-Hernández, E., Reina-Medrano, J., \& Colombia, B. (2021). Strengthening Motivation in the Mathematical Engineering Teaching Processes-A Proposal from Gamification and Game-Based Learning. International Journal of Emerging Technologies in Learning, 16(6). https://doi.org/10.3991/ijet.v16i06.16163

[30] Engelhardt, L. M. (2015). Simulating Price-Taking. The Journal of Economic Education, 46(4), 430-439. https://doi.org/10.1080/00220485.2015.1071219

[31] Pedraz, P. (2017). Dinámicas y mecánicas en Gamificación: esas grandes desconocidas (o no). Recuperado el 23 de septiembre de 2018, de https://www.alaluzdeunabombilla .com/2017/08/29/dinamicas-y-mecanicas-esas-grandes-desconocidas-o-no/

[32] Merodio Consultores. (2018). Instrumento Herrmann de Dominancia Cerebral. Recuperado de https://www.u-cursos.cl/diplomados/2011/2/DGE4/1/material_docente/bajar?id_ material $=406066$

[33] Velásquez Burgos, B. M., Remolina de Cleves, N., \& Calle, M. G. (2003). Determinación del perfil de dominancia cerebral o formas de pensamiento de los estudiantes de primer semestre del programa de bacteriología y laboratorio clínico de la Universidad Colegio Mayor de Cundinamarca. Nova, 5(7), 48-56. Recuperado de https://repository.unad .edu.co/handle/10596/6769. https://doi.org/10.22490/24629448.373

\section{Authors}

Jhonatan Alexander Moreno-Delacruz is an economist, master in management for social innovation and is studying a doctorate in territorial management. He is a university professor and an academic coordinator of the Economics program at the Universidad del Cauca in Colombia. He is also a researcher of the Interdisciplinary Group in Cultural, Economic and Administrative Studies - GICEA and editor of Revista Perspectivas (ISBN 2011-7345) of the Corporación Universitaria Comfacauca in Colombia (jalexmd@unicauca.edu.co).

Isabel Cristina Rivera-Lozada is an economist and holds a $\mathrm{PhD}$ in education. She is a researcher and a professor at the Universidad del Cauca, Colombia. Ms Rivera is a national and international consultant in the design of flexible formal and non-formal education models. She is an active researcher in education, gender, conflict, health economics and entrepreneurship in Latin American research groups and social organizations. She is currently a member of the Central Curricular Committee of the Universidad del Cauca and a member of the editorial committee of the Revista de Investigación de la Universidad Privada Norbert Wiener and Mesa de Economía Feminista del Cauca.

Oriana Rivera-Lozada is a researcher in epidemiology, public health and health education. She is recognized as a CONCYTEC Researcher (National Registry of Researchers in Science and Technology, REGINA, no. P0011631). Her scientific production includes books and scientific articles published in important databases. She is also Director for Peru of the Joanna Briggs Institute (JBI) and Coordinator of the South American Center for Education and Research in Public Health. She is a member of editorial committees of indexed journals and is a member of the Sigma Xi 
Paper-Research in the Classroom: The Teaching of Economics and Gamification

scientific society (The scientific Research Honor Society) and Council on Undergraduate Research (CUR) (oriana.rivera@uwiener.edu.pe).

Article submitted 2021-04-21. Resubmitted 2021-05-20. Final acceptance 2021-05-20. Final version published as submitted by the authors. 